\title{
Effect of Thermal Processing on the Nutritional, Antinutritional, and Antioxidant Properties of Tetracarpidium conophorum (African Walnut)
}

\author{
S. Olanrewaju Arinola and Kunle Adesina \\ Department of Food Technology, Federal Polytechnic Ado Ekiti, Ado Ekiti 360231, Ekiti State, Nigeria \\ Correspondence should be addressed to S. Olanrewaju Arinola; lanrearinola@yahoo.com
}

Received 29 May 2014; Revised 11 October 2014; Accepted 11 October 2014; Published 9 November 2014

Academic Editor: Franco P. Pedreschi

Copyright (c) 2014 S. O. Arinola and K. Adesina. This is an open access article distributed under the Creative Commons Attribution License, which permits unrestricted use, distribution, and reproduction in any medium, provided the original work is properly cited.

The effect of thermal processing (roasting and boiling) on the nutritional, antinutritional, and antioxidant properties of African walnut was studied. Tetracarpidium conophorum (African walnut) was subjected to thermal treatment of roasting (RWIS), boiling with shell (BWIS), and boiling without shell (BWOS). The resulting samples with raw nut (RAAW) which served as control were analysed for proximate composition, antinutritional components, and antioxidant activity. The protein, fat, and ash contents of the samples on dry basis were $29.14 \%, 54.14 \%$, and $3.32 \%$ (RAAW); $24.13 \%, 61.75 \%$, and $2.77 \%$ (BWIS); $22.47 \%$, $62.65 \%$, and $2.16 \%$ (BWOS); and $24.25 \%, 60.52 \%$, and $2.48 \%$ (RWIS), respectively. Thermal processing had significant effect on all the proximate principles; boiling and roasting generally reduced the protein and ash contents of the nut. Boiling with or without shell reduced the phytate and tannin contents of the nut while roasting increased the level of these two antinutritional components; walnut boiled without shell however, had the lowest phytate and tannin contents of $0.815 \mathrm{mg} / 100 \mathrm{~g}$ and $0.239 \mathrm{mg} / 100 \mathrm{~g}$, respectively. The antioxidant activities of the samples were $8.47 \%$ (RAAW), 13.82\% (BWIS), 14.96\% (BWOS), and 7.29\% (RWIS). This study reveals that thermal processing has a significant effect on the proximate principles, bioavailability, and antioxidant activity of African walnut.

\section{Introduction}

Tetracarpidium conophorum is a woody perennial climbing plant which is commonly cultivated for the production of nuts (African walnut); it is usually found in some states of south-west and south-south geopolitical regions of Nigeria. African nut which is usually cooked and consumed as snacks has been identified to possess both nutritional and medicinal values. Enujiugba [1] and Ogunsua and Adebona [2] have reported on the high nutritional potential of the nut. African walnut has been known to possess antioxidant property [3] which is as a result of its constituent bioactive polyphenols. There is evidence that phenolic substances act as antioxidant by preventing the oxidation of LDL-lipoprotein, platelet aggregation, and damage of red blood cells [4]; this explains the reason that made the nut to be listed among the plant foods that are of great health benefit to human body. The nut has also been used as a male fertility agent in the southern part of Nigeria. African walnut is also known to contain some antinutritional chemical components such as phytate and tannin which have been reported to be responsible for the bitter taste usually observed upon drinking of water immediately after consumption of the nut.

Food materials are usually processed in order to improve palatability and reduce toxicity and as a means of preservation [5]. Processing methods such as thermal processing, refrigeration, freezing, and fermentation have been applied to various food materials to achieve these purposes. Thermal or heat processing is one of the most important methods developed by man; during thermal processing antinutritional components are reduced or eliminated. However, heat processing also has a detrimental effect on the nutritional and functional properties of foods. It is therefore important that after processing there must be scientific evidence that nutritional and other useful properties are still of significant value and that antinutritional components have been reduced considerably. El Gharras [6] reported that the health effects of polyphenols vis-à-vis antioxidant property depend on their 
TABle 1: Proximate composition (dry basis) of raw and processed African walnut.

\begin{tabular}{|c|c|c|c|c|c|}
\hline & $\begin{array}{c}\text { Protein } \\
(\%)\end{array}$ & $\begin{array}{l}\text { Fat } \\
(\%)\end{array}$ & $\begin{array}{l}\text { Ash } \\
(\%)\end{array}$ & $\begin{array}{c}\text { Fiber } \\
(\%)\end{array}$ & $\begin{array}{c}\text { Carbohydrate } \\
(\%)\end{array}$ \\
\hline RAAW & $29.14 \pm 0.27^{\mathrm{a}}$ & $54.14 \pm 2.10^{\mathrm{b}}$ & $3.32 \pm 0.40^{\mathrm{a}}$ & $9.23 \pm 0.13^{\mathrm{a}}$ & $4.17 \pm 0.14^{\mathrm{c}}$ \\
\hline BWIS & $24.13 \pm 0.16^{\mathrm{b}}$ & $61.75 \pm 1.50^{\mathrm{a}}$ & $2.77 \pm 0.30^{\mathrm{b}}$ & $7.30 \pm 0.35^{\mathrm{c}}$ & $4.11 \pm 0.14^{\mathrm{c}}$ \\
\hline BWOS & $22.47 \pm 0.30^{c}$ & $62.65 \pm 1.40^{\mathrm{a}}$ & $2.16 \pm 0.20^{c}$ & $8.10 \pm 0.27^{\mathrm{b}}$ & $4.60 \pm 0.15^{\mathrm{b}}$ \\
\hline RWIS & $24.25 \pm 0.25^{\mathrm{b}}$ & $60.52 \pm 2.30^{\mathrm{a}}$ & $2.48 \pm 0.22^{\mathrm{bc}}$ & $7.35 \pm 0.30^{c}$ & $5.50 \pm 0.22^{\mathrm{a}}$ \\
\hline
\end{tabular}

RAAW = raw nut, BWIS = boiled with shell, BWOS = boiled without shell, and RWIS = roasted with shell.

Means of triplicate determination \pm standard deviation.

Values in the same column with different superscript are significantly different $(P \leq 0.05)$.

respective intakes and their bioavailability which can vary greatly. The objective of this research work was to evaluate the effect of thermal processing (roasting and boiling) on the nutritional, antinutritional, and antioxidant properties of African walnut.

\section{Materials and Methods}

2.1. Preparation of Sample. African Walnut (Tetracarpidium conophorum) was purchased at a local market in AdoEkiti, Ekiti state, Nigeria. The nuts were sorted, cleaned thoroughly with water, and divided into four lots. The first lot was boiled for $1.5 \mathrm{hrs}$, shelled, sliced, ground using electric blender, packaged in a polythene bag, and then stored in the refrigerator (BWIS). The second lot was shelled, boiled for $1.5 \mathrm{hrs}$, sliced, ground, packaged, and stored as above (BWOS). The third lot was roasted by continuous stirring in hot sand for $1 \mathrm{hr}$; it was then shelled, sliced, ground, packaged, and stored as above (RWIS). The last lot was used as control; the raw nut was shelled, sliced, ground, packaged, and stored as above (RAAW).

2.2. Proximate Analysis. The four samples of African walnut were subjected to proximate analysis using Official Methods of Analysis [7].

2.3. Antinutritional Analysis. Tannin content was determined by the method described by Pearson [8] while phytate was determined according to the method described by Oberlease, [9] with some modifications.

2.4. Antioxidant Activity Determination. The determination of the antioxidant activity of the samples was based on the ability of the extract of the samples to inhibit stable diphenyl picryl hydrazyl radical (DPPH). Exactly $0.5 \mathrm{~mL}$ of methanolic solution of DPPH $(1 \mathrm{mM})$ was added to $0.05 \mathrm{~mL}$ of $10 \%$ aqueous extract of the various walnut samples followed by the addition of $2 \mathrm{~mL}$ methanol; the mixture was placed in the dark for 30 mins. The absorbance of the solution was read at $517 \mathrm{~nm}$ using a spectrophotometer; the absorbance of blank (distilled water) was also taken. The antioxidant activity was calculated by the equation:

Antioxidant Activity $(\%)=\frac{(A \text { control }-A \text { sample })}{A \text { control }} \times 100$,

where $A=$ absorbance.
2.5. Statistical Analysis. Analytical determinations were done in triplicates and the results were expressed as mean score \pm standard deviation. The statistical significance of the observed differences among the means of triplicates was evaluated with the analysis of variance (ANOVA) while means were separated using Duncan's Range Test using SPSS 17.0 software package (Statistical Package for Social Scientists, Michigan, USA).

\section{Result and Discussion}

The result of the effect of thermal processing on the proximate composition of African walnut is shown on Table 1. The proximate composition of the raw nut which was comparable to that reported by Odoemelam [10] confirmed the nut as a rich source of fat and protein. There was significant difference in the protein content of the samples; boiling and roasting reduced the protein content of the nuts from $29.14 \%$ for raw nuts to $24.13 \%, 22.47 \%$, and $24.25 \%$ for nuts boiled with shell, nuts boiled without shell, and roasted nuts, respectively. As indicated in the result, boiling with shell and roasting preserve the protein content better than boiling without shell. Ijeh et al. [11] reported similar reduction in the protein contents of boiled and roasted African breadfruit (Treculia africana) seeds. The reduction in the protein content of African walnut during boiling and roasting may be due to denaturation and/or solubilisation of some nitrogenous compounds during processing.

The crude fiber contents of the samples ranged from $7.30 \%$ for nuts boiled with shell to $9.23 \%$ for raw nuts. The two processing methods employed in this study caused a significant reduction in the crude fiber content of African walnut; the values of crude fiber reported for all the walnut samples in this study were higher than $3.2 \%$ reported for cashew nut [12]. Crude fiber in diet is known to enhance digestibility, slow down the release of glucose into blood stream, aid bowel movement, and prevent bowel cancers. Expectedly the fat contents of processed nut samples with a range of $60.52 \%$ to $62.65 \%$ were significantly higher than that of raw nut sample (54.14\%); there was, however, no significant difference between the fat contents of processed nuts, sample boiled without shell had the highest fat content of $62.65 \%$. Application of dry heat has been known to facilitate release and extraction of oil in oilseed. The ash content of the nuts boiled without shell was the lowest; this may be as a result of leaching of some mineral nutrient during hydrothermal 
TABLE 2: Antinutritional components and antioxidant activity of raw and processed African Walnut.

\begin{tabular}{lccc}
\hline & $\begin{array}{c}\text { Phytate } \\
(\mathrm{mg} / 100 \mathrm{~g})\end{array}$ & $\begin{array}{c}\text { Tannin } \\
(\mathrm{mg} / 100 \mathrm{~g})\end{array}$ & $\begin{array}{c}\text { Antioxidant } \\
\text { activity } \\
(\%)\end{array}$ \\
\hline RAAW & $0.959 \pm 0.003^{\mathrm{b}}$ & $0.270 \pm 0.002^{\mathrm{b}}$ & $8.47 \pm 0.10^{\mathrm{c}}$ \\
BWIS & $0.903 \pm 0.002^{\mathrm{c}}$ & $0.251 \pm 0.003^{\mathrm{c}}$ & $13.82 \pm 0.20^{\mathrm{b}}$ \\
BWOS & $0.815 \pm 0.002^{\mathrm{d}}$ & $0.239 \pm 0.001^{\mathrm{d}}$ & $14.96 \pm 0.20^{\mathrm{a}}$ \\
RWIS & $1.354 \pm 0.004^{\mathrm{a}}$ & $0.286 \pm 0.002^{\mathrm{a}}$ & $7.29 \pm 0.10^{\mathrm{d}}$ \\
\hline
\end{tabular}

RAAW = raw nut, BWIS = boiled with shell, BWOS = boiled without shell, and RWIS = roasted with shell.

Means of triplicate determination \pm standard deviation.

Values in the same column with different superscript are significantly different $(P \leq 0.05)$

processing. The ash content of the raw nuts was significantly higher than that of other samples; however, there was no significant difference between the ash contents of sample boiled without shell and roasted sample. Boiling without shell and roasting significantly increased the carbohydrate content of raw African walnut from $4.17 \%$ to $4.60 \%$ and $5.50 \%$ for sample boiled without shell and roasted sample, respectively. This could probably be due to the relative reduction in protein content and hydrolysis effect on the carbohydrate store in the nuts making it readily available. This pattern of results has equally been reported by other researchers on the starch content of raw and cooked peas as well as other legumes [13].

The antinutritional components and the antioxidant activity of the four samples of African walnut are presented in Table 2. Antinutritional components are known to reduce the bioavailability of nutrients in the body; phytate chelates mineral elements and makes them metabolically unavailable [14] while tannin forms insoluble complexes with protein thereby reducing protein bioavailability. Boiling significantly reduced the phytate contents of the nuts; the reduction in phytate content may partly be due to leaching into the cooking medium, degradation by heat, and formation of insoluble complexes between phytate and other components such as protein and minerals [15]. Boiling of African walnut also resulted in reduction of tannin content of the nuts; this reduction can be attributed to the leaching out of phenols into the cooking medium under the influence of concentration gradient [16]. Tannins are polyphenols and all polyphenolic compounds are known to be water soluble in nature. Udensi et al. [17] had reported similar result of loss of phytate and tannin contents of vegetable cowpea (Sesquipedalis) seeds during boiling. Boiling without shell resulted in higher reduction of both antinutritional components than boiling with shell. Roasting generally led to increase in the level of these antinutritional components in the nuts; this pattern of results was similar to what was reported by Enujiugba [1]. Ekwe and Ihemeje [18] have also reported that toasting caused an increase in the phytate and tannin content of African walnut. This result shows that boiling especially without the shell can significantly improve the bioavailability of nutrients in African walnut. Thermal processing has a major effect on the antioxidant activity of African walnut as there was significant difference in the antioxidant activity of all of the four samples. Lima et al. [19] have reported that domestic processing such as boiling and roasting seems to have a dramatic effect on phenolic content of foods and as a consequence on antioxidant activity. While boiling, either with or without shell, increases the antioxidant activity significantly, roasting reduces the antioxidant activity of the nut. This result is consistent with the report of Castillo et al. [20], who reported that roasting causes progressive decrease in the antioxidant activity of coffee beans.

\section{Conclusion}

This study established the fact that thermal processing especially boiling without shell can significantly improve the bioavailability of nutrients and antioxidant activity of Tetracarpidium conophorum (African walnut). It also confirmed previous report that Tetracarpidium conophorum (African walnut) is a rich source of protein and fat; however, thermal processing reduced the protein, ash, and crude fiber content of the nut.

\section{Conflict of Interests}

The authors have no conflict of interests regarding the publication of this paper.

\section{References}

[1] V. N. Enujiugba, "Chemical and functional characteristics of conophor nut," Pakistan Journal of Nutrition, vol. 2, no. 6, pp. 335-338, 2003.

[2] A. O. Ogunsua and M. B. Adebona, "Chemical composition of Tetracarpidium conophorum (conophor nut)," Food Chemistry, vol. 10, no. 3, pp. 173-177, 1983.

[3] B. M. Olabinri, O. O. Eniyansoro, C. O. Okoronkwo, P. F. Olabinri, and M. T. Olaleye, "Evaluation of chelating ability of aqueous extract of Tetracarpidium conophorum (African walnut) in vitro," International Journal of Applied Research in Natural Products, vol. 3, no. 3, pp. 13-18, 2010.

[4] V. Cheynier, "Polyphenols in foods are more complex than often thought," The American journal of clinical nutrition, vol. 81, supplement 1, pp. 223S-229S, 2005.

[5] M. A. Ayankunbi, O. O. Keshinro, and P. Egele, "Effect of methods of preparation on the nutrient composition of some cassava products-Garri (eba), "Lafun" and "Fufu'"' Food Chemistry, vol. 41, no. 3, pp. 349-354, 1991.

[6] H. El Gharras, "Polyphenols: food sources, properties and applications-a review," International Journal of Food Science \& Technology, vol. 44, no. 12, pp. 2512-2518, 2009.

[7] AOAC, Official Method of Analysis, Association of Official Analytical Chemist, Washington, DC, USA, 15th edition, 1990.

[8] D. A. Pearson, Chemical Analysis of Foods, Churchill Livingstone, Edinburgh, UK, 7th edition, 1976.

[9] D. Oberlease, "Phytate," in Toxicants Occurring Naturally in Foods, F. Strong, Ed., pp. 363-371, National Academy of Sciences, Washington, DC, USA, 1973.

[10] S. A. Odoemelam, "Chemical composition and functional properties of conophor nut (Tetracarpidium conophorum) flour," International Journal of Food Science and Technology, vol. 38, no. 6, pp. 729-734, 2003. 
[11] I. I. Ijeh, C. E. Ejike, O. M. Nkwonta, and B. C. Njoku, "Effect of traditional processing techniques on the nutritional and phytochemical compositions of African breadfruit (Treculia africana) seeds," Journal of Applied Science and Environmental Management, vol. 14, no. 4, pp. 169-173, 2010.

[12] T. F. Akinhanmi, V. N. Atasie, and P. O. Akintokun, "Chemical composition and physicochemical properties of cashew nut (Anacardium occidentale) oil and cashew nut shell liquid," Journal of Agricultural, Food, and Environmental Sciences, vol. 2, no. 1, pp. 1-10, 2008.

[13] G. E. De Almeida Costa, K. Da Silva Queiroz-Monici, S. M. P. M. Reis, and A. C. De Oliveira, "Chemical composition, dietary fibre and resistant starch contents of raw and cooked pea, common bean, chickpea and lentil legumes," Food Chemistry, vol. 94, no. 3, pp. 327-330, 2006.

[14] C. Nduagu, E. J. Ekefan, and A. O. Nwankiti, "Effect of some crude plant extracts on growth of Colletotrichum capsici (Synd) and Bisby, causal agent of pepper anthracnose," Journal of Applied Biosciences, vol. 6, no. 2, pp. 184-190, 2008.

[15] P. Siddhuraju and K. Becker, "Preliminary nutritional evaluation of Mucuna seed meal (Mucuna pruriens var. utilis) in common carp (Cyprinus carpio L.): an assessment by growth performance and feed utilisation," Aquaculture, vol. 196, no. 1-2, pp. 105-123, 2001.

[16] K. Vijayakumari, P. Siddhuraju, and K. Janardhanan, "Effect of domestic processing on the levels of certain antinutrients in Prosopis chilensis (Molina) Stunz. seeds," Food Chemistry, vol. 59, no. 3, pp. 367-371, 1997.

[17] E. A. Udensi, F. C. Ekwu, and J. N. Isinguzo, "Antinutrient factors of vegetable cowpea (Sesquipedalis) seeds during thermal processing," Pakistan Journal of Nutrition, vol. 6, no. 2, pp. 194197, 2007.

[18] C. C. Ekwe and A. Ihemeje, "Evaluation of physiochemical properties and preservation of African walnut (Tetracarpidium conophorum)," Academic Research International, vol. 4, no. 6, pp. 501-512, 2013.

[19] G. P. P. Lima, T. D. V. C. Lopes, M. R. M. Rossetto, and F. Vianello, "Nutritional composition, phenolic compounds, nitrate content in eatable vegetables obtained by conventional and certified organic grown culture subject to thermal treatment," International Journal of Food Science \& Technology, vol. 44, no. 6, pp. 1118-1124, 2009.

[20] M. D. Castillo, J. M. Ames, and M. H. Gordon, "Effect of roasting on the antioxidant activity of coffee brews," Journal of Agriculture and Food Chemistry, vol. 50, no. 13, pp. 3698-3703, 2002. 

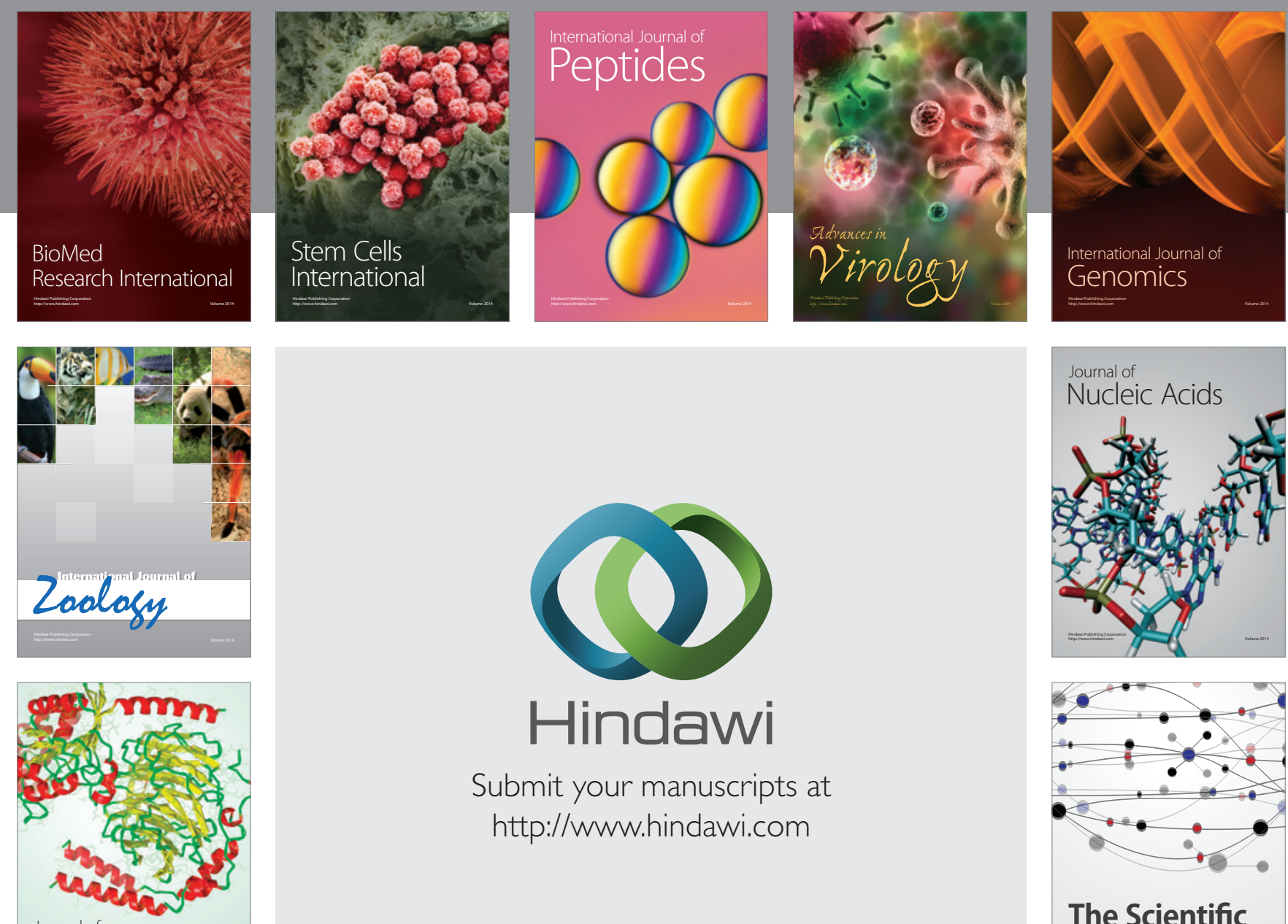

Submit your manuscripts at

http://www.hindawi.com

Journal of
Signal Transduction
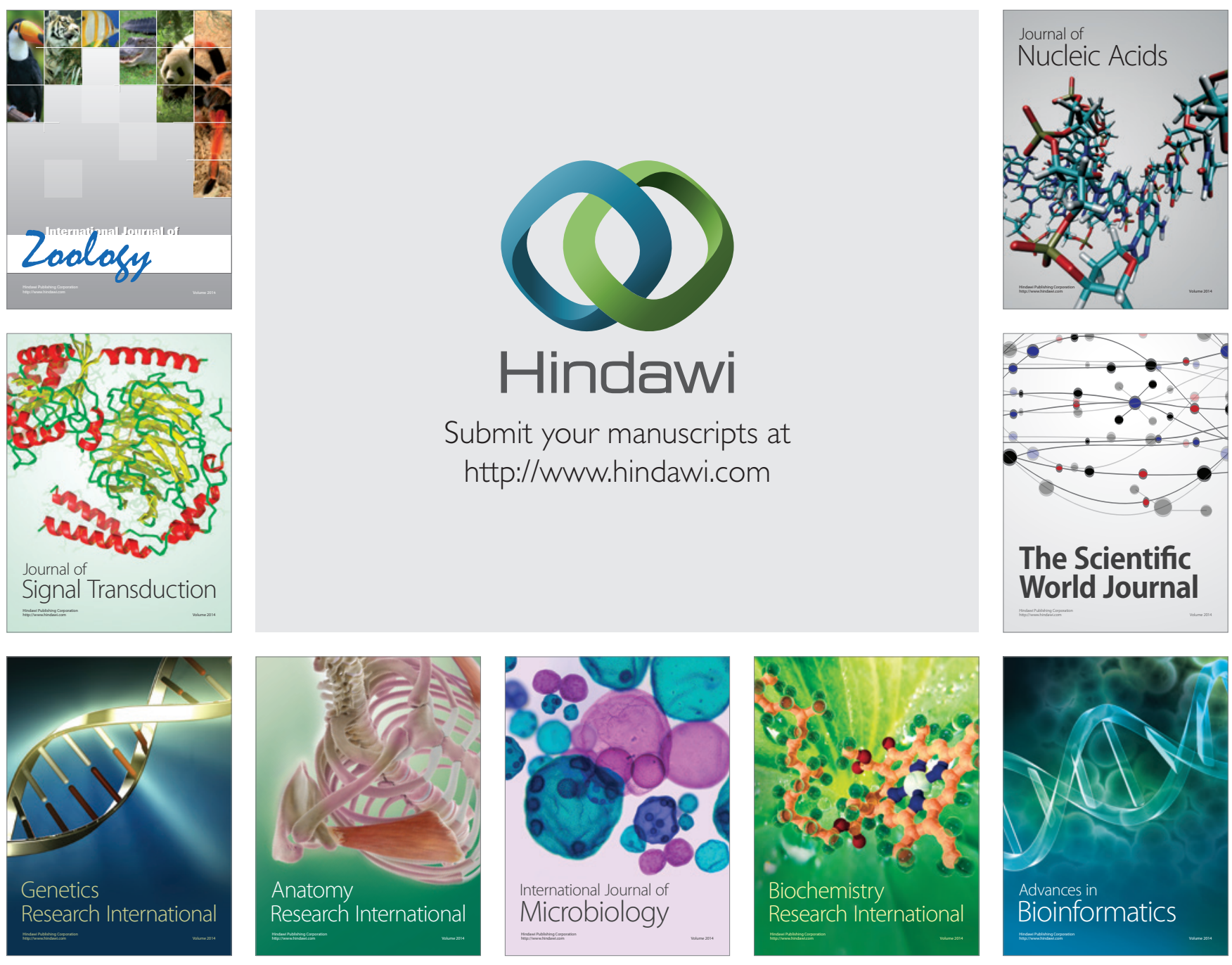

The Scientific World Journal
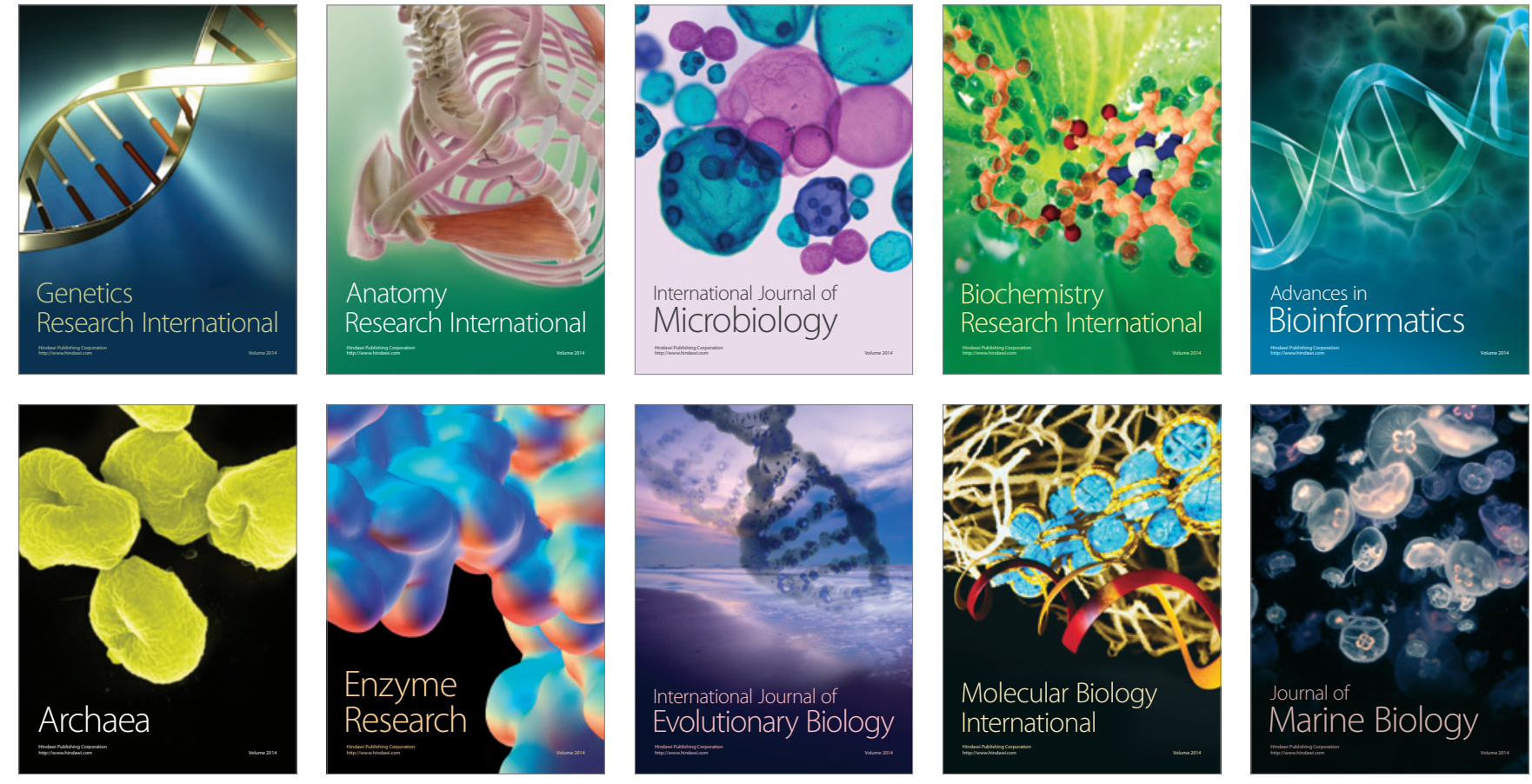